\title{
Workers, Unions, and Workplaces in Dubuque, 1830-1990
}

\author{
RALPH SCHARNAU
}

A HUNDRED YEARS AGO, Dubuque acquired a reputation as Iowa's leading industrial city. A Mississippi River metropolis with its terrain compactly laced by streets, homes, stores, and manufacturing sites, Dubuque remains a largely self-contained urban center with significant local and regional commercial activities. The city's diverse business establishments and robust trade area attracted a large workingclass population. Traditionally dominated by German and Irish nationalities, the river city's wage earners preferred Catholicism in religion and the Democratic party in politics. A significant number of these laboring people joined trade unions to secure better wages, hours, and working conditions as well as a more humane social order.

Beginning in the nineteenth century, Dubuque, like cities across the United States, experienced a series of transformations generated by industrialization. Those changes brought new enterprises and different work processes that local historians usually attribute to bold entrepreneurs, innovative products, and fascinating technology. Such a traditional

Other versions of this essay provided the script for a labor exhibit currently on display at the Iowa Welcome Center in Dubuque and for a slide show presentation at the Missouri Valley History Conference in Omaha on March 14, 1992. I acknowledge the noteworthy research and technical assistance of Roger Osborne, curator at the Dubuque County Historical Society. We discussed our collaborative experiences at a session of the Iowa Congress of Historical Organizations in Des Moines on June 13, 1992. Financial support for these projects came from the Iowa State LaborManagement Cooperation Council, the Iowa Humanities Board, and the Professional Development Committee at the University of Dubuque.

THE ANNALS OF IOWA 52 (Winter 1993). (C)The State Historical Society of Iowa, 1993. 
approach to economic history marginalizes or simply ignores the essential role of the working class. Those historians who do pay attention to workers, on the other hand, tend to focus on one industry or a narrow time frame.

This sweeping survey of the history of labor in Dubuque from the 1830s through the 1980s offers a collective profile of workers, their unions, and their workplaces, thus providing a link between industrial development and work issues. It emphasizes the centrality of labor, focusing on workers in the context of their employment and unionization patterns among leading local industries. The collective activity of Dubuque wage earners shaped the city's material culture and public image. Understanding their contributions to Dubuque's identity adds to our perceptions of the contours of labor history and its place in small to medium-sized midwestern industrial cities. It is also one good way to tell the story of a local community.

IOWA'S FIRST EUROPEAN SETTLERS made their home in the area that later became the city of Dubuque. In 1788 Julien Dubuque, a French-Canadian for whom the city is named, began to mine the lead ore on the bluffs overlooking the Mississippi River. Lead mining in the area peaked between 1835 and 1849, as Dubuque's mines became part of the foremost lead-producing district in the United States. Riverboats carried millions of pounds of lead ore to St. Louis, and hundreds of thousands of dollars poured into Dubuque. Then, with the depletion of superficial lead deposits and the discovery of gold in California, miners migrated out of the area and the industry languished. Before its demise, however, lead mining provided an occupation for many and a fortune for a few. ${ }^{1}$

The city itself was officially founded in 1833. Its first bank, appropriately named the Miner's Bank, opened the same year with a capital investment of one hundred thou-

1. Franklin T. Oldt, History of Dubuque County, Iowa ... (Chicago, [1912]), 19, 23-24, 46; Jack Brimeyer and John McCormick, Our Early Years (Dubuque, 1976), 24, 45, 47; Ralph Scharnau, "The Business and Industrial History of Dubuque, 1833-1900," in Russell W. Nash, comp., Dubuque Beginnings (Dubuque, 1985), 30-31. 


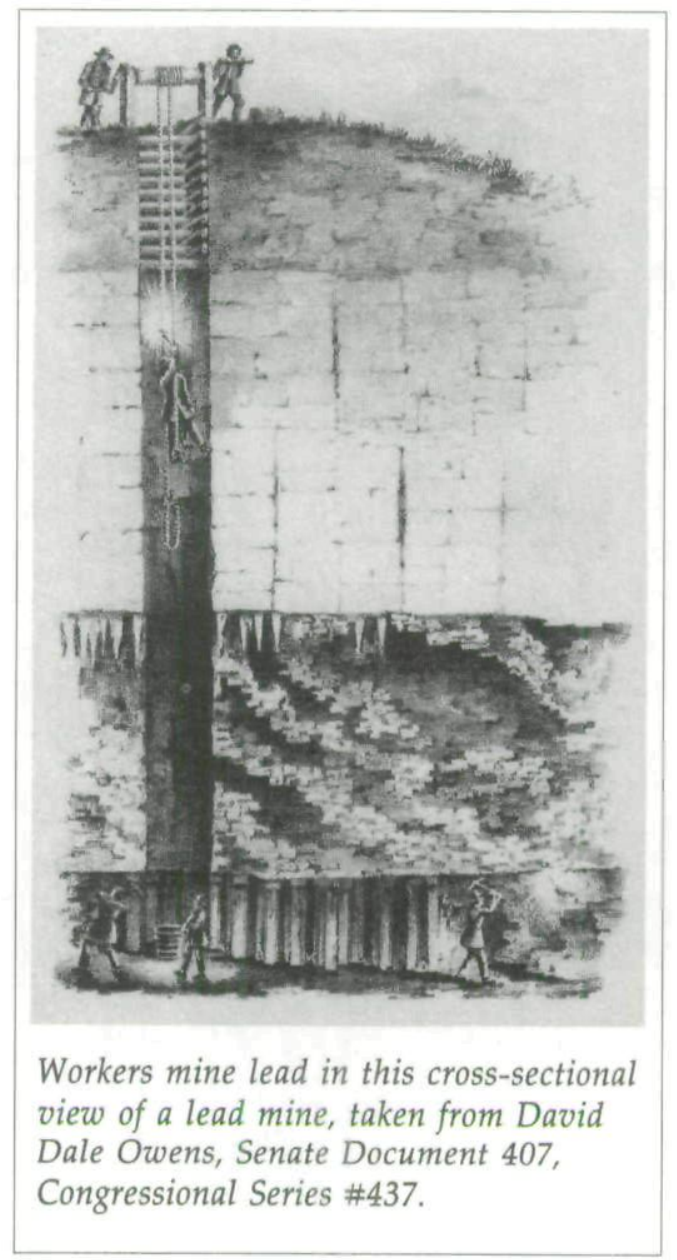

sand dollars. In succeeding generations new industries and new workers replaced the lead miners. By 1850, Dubuque had 3,108 residents, and by 1900 its population had grown to 36,297 . This nearly twelvefold growth in the last half of the nineteenth century exceeded the nation's growth rate by about a three-to-one margin. ${ }^{2}$ As the economy expanded, industrial jobs proliferated.

2. Scharnau, "Business and Industrial History of Dubuque," 30-31; William J. Petersen, "Dubuque-The Key City of Iowa," Palimpsest 45 (1964), 446; Donald J. Bogue, The Population of the United States: Historical Trends and Future Projections (New York, 1985), 73. 
Beginning in the late 1850 s, lumbering replaced lead mining as the city's principal industry. The Mississippi River carried log rafts from the pine forests of Wisconsin and Minnesota to the growing local wood enterprises. Sawmills, lumber yards, and woodworking plants dotted the landscape, generating huge fortunes for the timber barons and more than three thousand jobs for woodworkers. The sawmills and sprawling lumber yards stretching along the city's riverfront supplied sash and door mills. The largest of these mills-Carr, Ryder and Adams and Farley and Loetscher Manufacturing Company-employed up to two thousand workers during peak production periods. Wagon and carriage manufacturers also depended on the wood produced by the lumber industry. Two large firms-Connolly Carriage Manufactory and Cooper Wagon Works-produced nationally known vehicles and provided employment for nine hundred workers. ${ }^{3}$ By the end of the 1850 s, wood had become the new symbol of Dubuque's prosperity, overshadowing all other business enterprises.

In addition to wood products, meatpacking emerged as another important Dubuque industry. In 1884 the product value of the packinghouses amounted to two million dollars. Pork production became a thriving business because of the ease of raising hogs and the area's large corn crop. William Ryan operated the biggest packing plant, which employed 250 people. $^{4}$

Dubuque's other major industries included railroading, garment making, and metals fabricating. The city became the hub of an expanding rail network. Railway jobs meant not only track construction and train operation, but also large Milwaukee Road car repair and replacement shops where employment at times reached 1,500 to 2,000 . Clothing factories provided the principal employment for female wage earners. Several hundred young women worked in the needle

3. Mike Hendricks, "Dubuque's Economy: Changing Direction, Changing Shape," Special Section, Dubuque Telegraph Herald, 25 September 1983, 6-7; Scharnau, "Business and Industrial History," 31-32.

4. Daily Globe Journal, 9 November 1894; Scharnau, "Business and Industrial History," 32-33. 


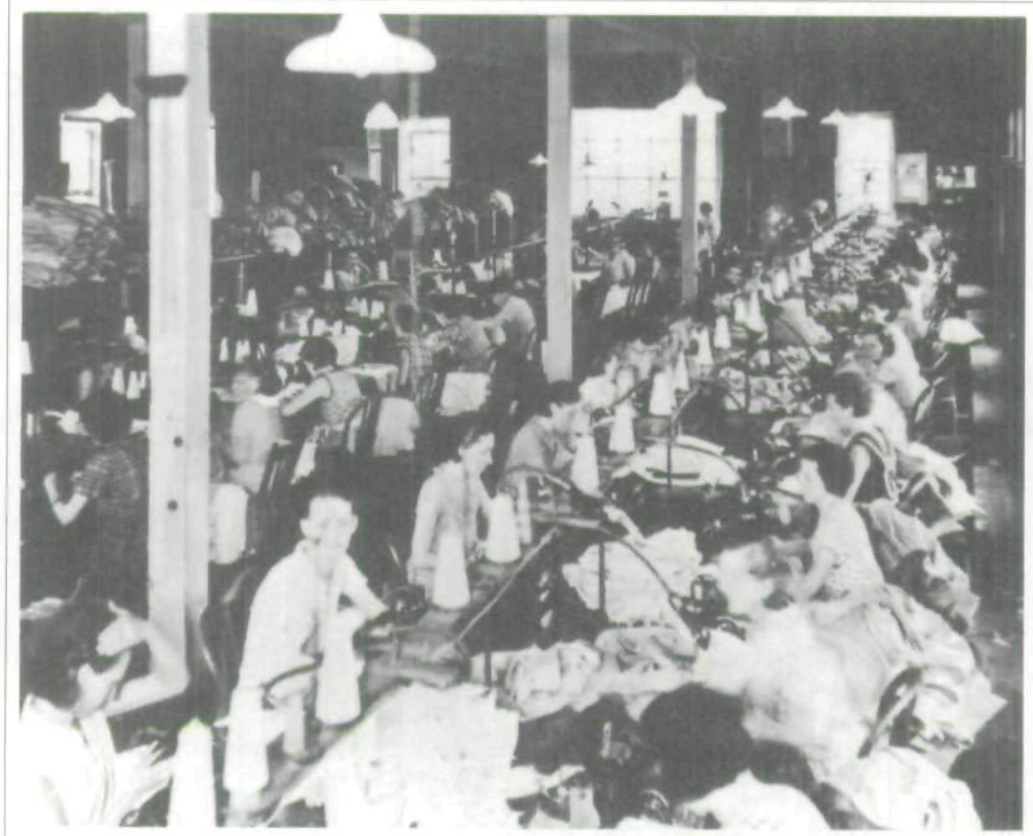

Women sew at their machines at the H. B. Glover Company in the 1930s, a scene reenacted in the 1950s musical comedy The Pajama Game. Courtesy of Bissell Collection, Center for Dubuque History, Loras College.

trades at H. B. Glover Company, making a nationally known brand of overalls; the company later gained fame as the setting for the 1950s musical comedy, The Pajama Game. Led by A. Y. McDonald Manufacturing Company and Klauer Manufacturing Company, at least a dozen firms employed nearly a thousand skilled workers in machine shops, foundries, and other metals fabricating plants. The metals workers produced pumps and plows, boats and boilers, and steam shovels and stoves as well as various hardware supplies. A sample of other products made in Dubuque includes shoes, mattresses, coffins, beer, cigars, soap, and candy. Nearly all of these products came from firms having fewer than two hundred employees. The city's economic well-being rested on a base of small and medium-sized business establishments. ${ }^{5}$

5. Scharnau, "Business and Industrial History," 29-30; Dubuque, The Key City of Iowa (Dubuque, 1889), 34, 36. 


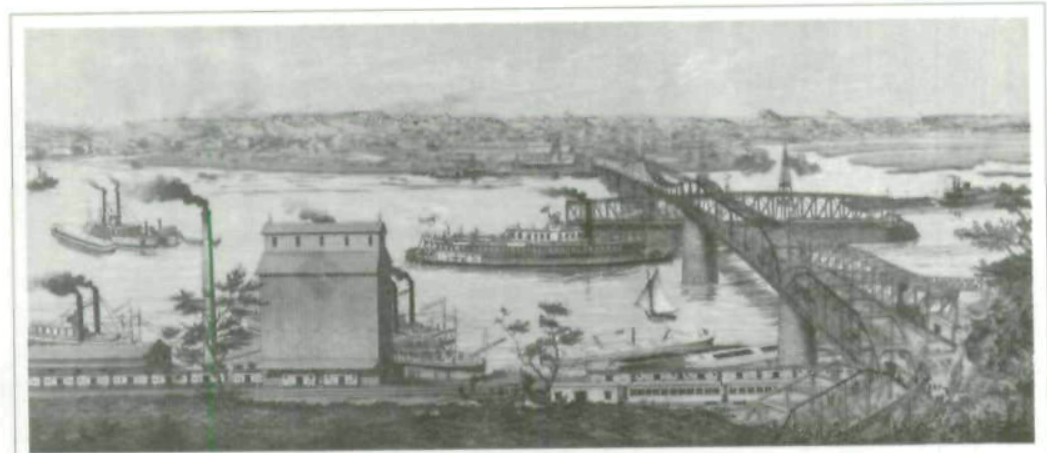

Artist Alex Simplot proudly recreated his vision of Dubuque's industrial strength in this 1887 drawing. Courtesy State Historical Society of Iowa.

During the 1880 s and 1890 s, Dubuque ranked first among Iowa cities in the number of manufacturing firms, average number of wage earners, and total wages. By 1900, the city's two hundred factories attested to its industrial strength. A 1903 Dubuque Telegraph Herald editorial proudly noted the city's manufacturing advantages as "an excellent water supply, ample fire protection, abundant ground, a large laboring population, good railroad connections, and river transportation." ${ }^{\prime 6}$

The rise of industrialism created many hardships for workers in the new and expanding factories and shops. They found themselves confronted with low pay, arrogant bosses, job insecurity, and exhausting work. The typical Dubuque worker in 1885 labored ten hours per day, six days per week. Workplace routines often included close supervision with few rest periods. Wage rates reflected discriminatory pay and job differentials based on gender, age, and race. Women and children received low pay for working in factories or in service occupations, such as clerks and domestics. Wage-earning women made one-third to one-half less money than men. Among children, boys received less pay than women, but more than girls. African-Americans, less than one percent of Dubuque's total population, usually could find only poorpaying jobs as servants, waiters and cooks, or porters. With-

6. Iowa Writers' Program, Work Projects Administration, Dubuque County History (Dubuque, 1942), 66; Iowa Bureau of Labor, Ninth Biennial Report ... 1899-1900, 89-90, 93-94; Dubuque Telegraph Herald, 4 January 1903. 
out workplace health and safety codes, working-class neighborhoods buzzed with grisly accounts of death, maiming, and other job-related injuries and diseases from unguarded machinery, fires, explosions, bad ventilation, and unsanitary conditions. No compensation awaited those who suffered workplace injuries or sicknesses. Neither could older workers expect pensions. Considering food, clothing, and housing expenses, Dubuque's unskilled and semiskilled workers frequently fell into debt and could maintain, at best, a meager standard of living. ${ }^{7}$

Confronting these realities and having no voice in the terms or conditions of their employment, workers turned to collective associations, or unions. The act of organizing a union, seeking company recognition, and negotiating a contract was, however, a process fraught with peril. Opposition to forming and sustaining trade unions came from several sources. Employers resisted labor unions by refusing to recognize organized workers, administering oppressive work rules, dismissing union organizers, enforcing yellow-dog contracts, utilizing lockouts, and hiring strikebreakers. Public officials usually sided with management in labor disputes; courts issued anti-union injunctions; and local police, state militia, and even the United States Army stood ready to crush strikes. Such resistance to labor organizations combined with recurrent hard times to weaken or destroy early trade unions. Despite these obstacles, wage earners continued their struggle to found unions and to seek protective labor legislation. Eventually, Dubuque became Iowa's premier locality for organized labor as well as its largest nineteenth-century manufacturing city.

Dubuque Typographical Union No. 22, Iowa's oldest craft organization, was chartered in 1855 . By the early 1880 s, cigarmakers, locomotive firemen and engineers, tailors, and blacksmiths had formed unions. The membership of these labor bodies ranged from twenty to thirty persons, all of

7. Ralph Scharnau, "Workers and Politics: The Knights of Labor in Dubuque, Iowa, 1885-1890," Annals of Iowa 48 (1987), 355-56, 359-60; Brimeyer and McCormick, Our Spirited Years, 39; Dubuque Industrial Leader, 1 January, 25 June, 15 October 1887. 
whom were white, male, and skilled. At their regular weekly meetings, these small unions limited their discussions to wage rates, work rules, and other ways of protecting their own exclusive membership; they avoided advocating independent politics. ${ }^{8}$

This circumscribed unionism changed dramatically when the Knights of Labor, a national labor association formed in 1869, launched a membership drive in Dubuque. A Knights of Labor organizer came to the city in 1885, and within two years Knights enrollment peaked at twenty-five hundred. Led by John Stafford, a skillful and aggressive young blacksmith, the Knights created the city's first mass labor movement by welcoming women, African-Americans, and recent European immigrants, as well as the unskilled, to its ranks. On the economic front, the Dubuque Knights of Labor started several cooperative enterprises, a weekly labor paper, a general store, and a heating fuel venture. On the political front, they lobbied for labor legislation, endorsed candidates friendly to labor, and finally formed a third party. Under the title of the Labor Reform party, the Knights scored a stunning local election victory in the spring of 1887 . After running city hall in a moderately progressive manner for one year, the Knights ticket suffered defeat in 1888 when the two major parties formed a fusion slate. Although the Dubuque Knights of Labor faded by the 1890s, they left a legacy of inclusive organizing, economic self-help, and political activism. ${ }^{9}$

The period from 1890 to 1910 brought the rise of numerous trade unions affiliated with the American Federation of Labor, a national organization of craft unions founded in 1886. First organized in 1888, the Dubuque Trades and Labor Congress, a citywide federation of trade unions, affiliated with the American Federation of Labor in 1900. The first issue of a new union weekly, the Labor Leader, appeared in 1906. Unions grew rapidly in the city's building trade occupations: carpenters, bricklayers, plumbers, stone cutters, cement workers, sheet metal workers, painters, lathers, and

8. Scharnau, "Workers and Politics," 356; Dubuque Leader, 50th Anniversary Edition, 31 August 1956.

9. Scharnau, "Workers and Politics," 353-77. 
construction laborers. New locals also appeared among coopers, teamsters, iron molders, electrical workers, printers, metal polishers, and button workers. In the service sector of the local economy, retail clerks, barbers, stagehands, bartenders, laundry workers, bakers, letter carriers, and musicians also formed unions. ${ }^{10}$

The rapid unionization of so many occupations partly reflected the city's reputation as a low-wage town. Conflicts with employers often centered on the issue of wage rates. Beginning in the 1880 s, walkouts occurred among tailors, printers, railway workers, overall workers, molders, and cigarmakers. During the 1890 s, strike activity intensified. Most of these labor stoppages originated in reaction to wage cuts. Sometimes grievances over hours, work rules, and union recognition precipitated or contributed to turnouts. ${ }^{11}$

Perhaps the most dramatic strike in the labor history of Dubuque occurred in 1903. Streetcar workers, rebuffed by management in their drive to secure union recognition and improved working conditions, initiated a strike and boycott that halted the city's mass transit system for seven weeks. During the course of the public sector confrontation, the privately owned trolley company imported, armed, and deputized strikebreakers from Chicago; secured a court injunction that restrained freedom of speech and peaceful protest; and threatened strikers with the menacing presence of the local police and state militia. Although defeated, the striking streetcar workers avoided violent conduct, won widespread public sympathy, and maintained their union organization. ${ }^{12}$

If the year 1903 marked the city's most famous strike, it also marked the year when the local trade union movement reached the pinnacle of its power and influence. Union mem-

10. Dubuque Leader, 31 August, 14 September 1956.

11. Dubuque Herald, 6-10 October 1880, 21, 23, 26 November, 3 December 1882, 10-12 April 1883, 10 April 1884, 7-19 April 1885, 13 April 1888, 24, 25 June 1890, 24 January, 5-12 May, 28 October, 10 November 1891, 24 September 1893, 20 March, 8-28 April, 3-5 May, 30 June-23 July 1894, 28 February 1896, 22 May 1898, 1, 7 May, 14 July, 17 September 1899, 10 May 1900; Dubuque Times, 3 April 1885.

12. Ralph Scharnau, "The Dubuque Streetcar Strike, 1903," forthcoming in Labor's Heritage. 
bership totaled about four thousand scattered among more than sixty locals. Although a few locals had several hundred members, most averaged thirty to forty. These gains for organized labor partly reflected the organizing skills of a small band of socialists. Socialists held leadership posts in the Dubuque Trades and Labor Congress and published a weekly paper, the Iowa Socialist. Led by iron molder Michael Milan and printer F. A. Lymburner, Dubuque socialists agitated for workers' rights and union principles and fueled the burst of union organizing in 1902 and 1903. By the end of the latter year, estimates of unionization ran as high as twothirds of the work force. Unionized workers dominated the vital transportation and construction sectors of the local economy. ${ }^{13}$

At the beginning of the twentieth century, Dubuque appeared destined for continued growth and prosperity. The city possessed a firm and varied economic foundation. The reputation of this thriving midwestern community rested on three foundations: Dubuque was a leading industrial center with a large working-class populace and strong unions.

DESPITE THE BRIGHT PROMISE of a new century of progress, the period between 1900 and 1940 was disappointing for Dubuque: the city's population increased just 20 percent, few new industries opened, several large companies left, and some prominent firms closed. The two hundred manufacturers in 1900 dwindled to ninety by $1940 .{ }^{14}$ A weakened labor movement tried without success to boost the low wage scales at the remaining factories.

The centralization of business contributed to the decline of manufacturing in Dubuque. Powerful industrial corporations built massive new factories in large cities. Mid-sized cities such as Dubuque found themselves bypassed and facing disastrous competition. Industry in Dubuque remained concentrated in family-owned businesses, most of

13. Ibid.

14. Petersen, "Dubuque," 446; Iowa Writers' Program, Dubuque County History, 66; Hendricks, "Dubuque's Economy," 7. 


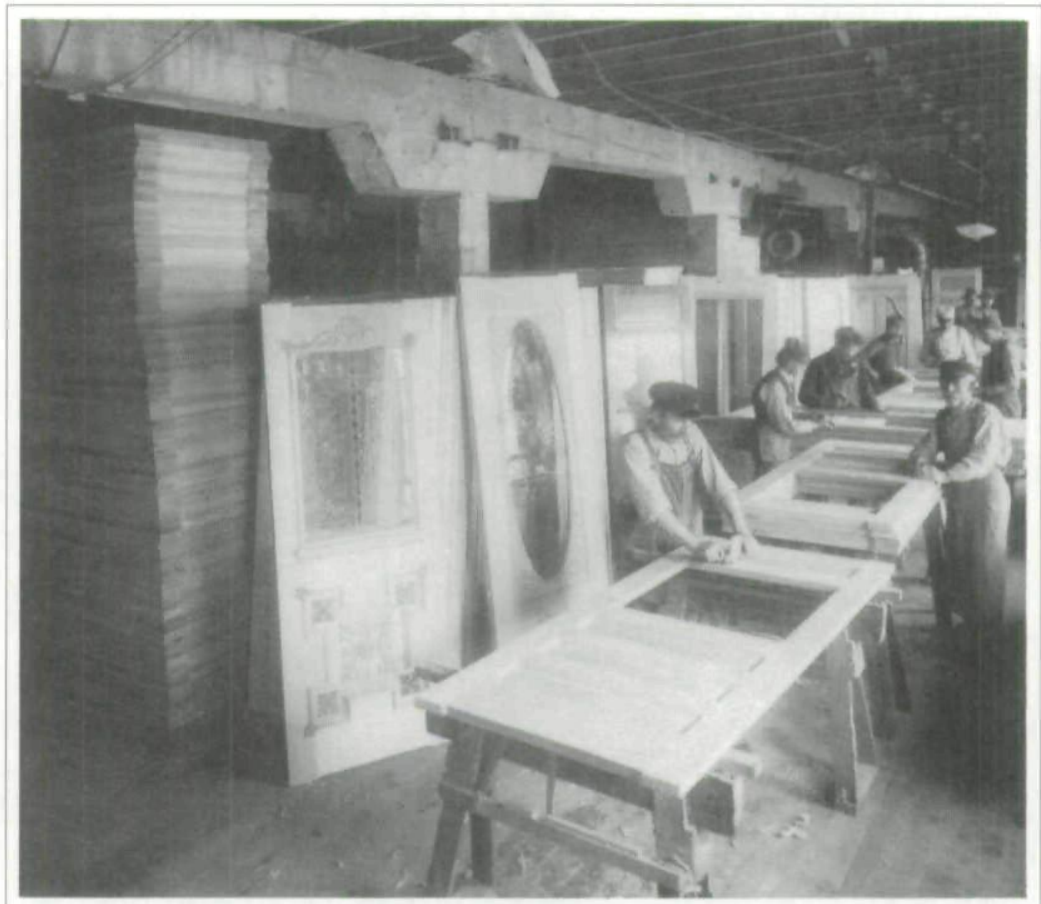

Craftsmen make doors at Farley and Loetscher Manufacturing Company sometime after the company expanded its plant about 1910. Courtesy State Historical Society of Iowa.

which lacked the capital to undertake plant expansions or initiate new enterprises.

Among the wood-related industries that disappeared were the once great lumberyards and the famous wagon and carriage works. The lumberyards succumbed in the face of depletion of the northern pine forests and the shift of the lumber business to the Northwest and South. The two largest yards, Knapp-Stout Lumber Company and Standard Lumber Company, also suffered enormous losses from fires. After three fires in an eleven-month period during the years 1911 and 1912, Standard Lumber ceased operations, causing the loss of five hundred jobs. Successive fires also ravaged Connolly's carriage plant and Cooper's wagon factory. Both companies recovered but refused to convert to automobile production. After production declines and work force cut- 


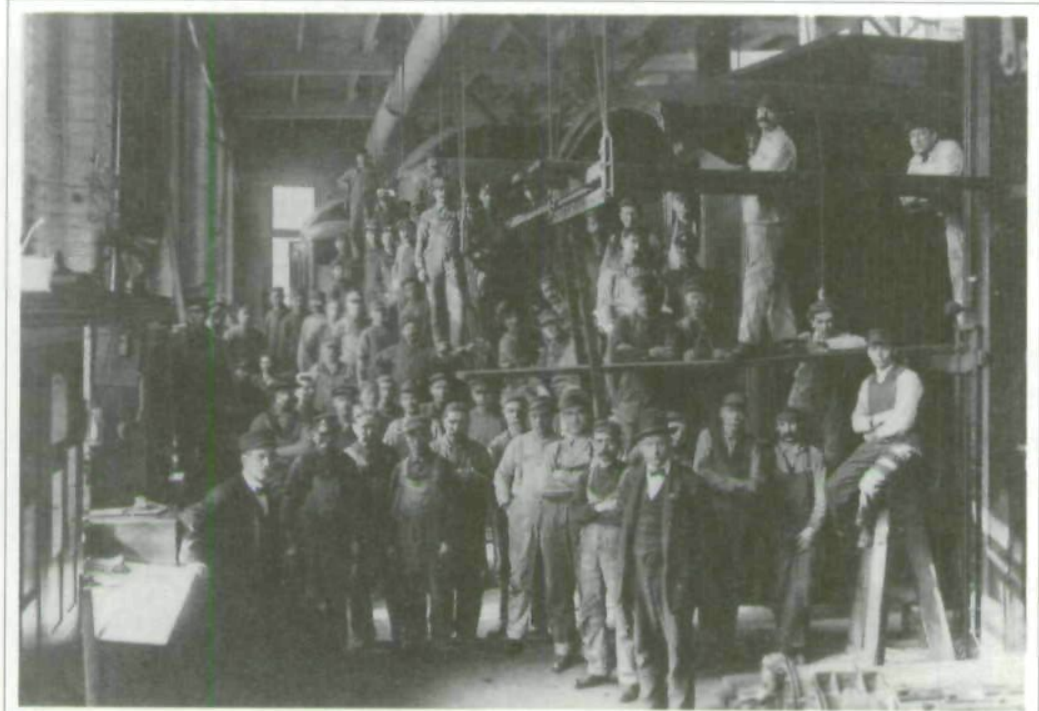

Railroad workers pose at the Milwaukee Road shop about the turn of the century. Courtesy Dubuque County Historical Society.

backs, both firms expired by the 1930s, victims of the emergent car culture. ${ }^{15}$

Yet one prominent segment of the wood industry continued to prosper. The sash and door mills enjoyed healthy profits during the first two decades of the twentieth century. With a work force of two thousand, the Farley and Loetscher and the Carr, Ryder and Adams mills were among the largest in the world. The woodworking mills maintained high employment, paid low wages, and kept unions out. Carpenters failed to gain union recognition or higher wages in a 1907 strike against the mills. ${ }^{16}$

Unlike the millworkers, most railway employees belonged to unions with collective bargaining rights. They negotiated contracts and received good wages. The Milwaukee shops employed two thousand, a vast majority of all local rail

15. Scharnau, "Business and Industrial History," 31-32; Hendricks, "Dubuque's Economy," 6, 7; Brimeyer and McCormick, Our Spirited Years, 33-36, 41.

16. Hendricks, "Dubuque's Economy," 7, 8; Dubuque Telegraph Herald, 30 April, 2 July, 21 December 1907, 15, 18 January 1908. 
workers. Railroads, the city's largest employer, had become a mainstay of the Dubuque economy and a stronghold of the labor movement in the years after $1900 .{ }^{17}$

Another industry that promised to strengthen the local economy was Brunswick-Balke-Collender. Commencing operations in 1912, Brunswick produced phonograph cabinets and radio housings, as well as some bar furniture and billiard tables, and paid relatively high wages. Upon reaching 850 employees in 1919, a number of craft unionists employed at the plant sought to establish a closed shop, where union membership would become a condition of employment. The company adamantly refused to consider the workers' request. Following the dismissal of several union organizers, a strike ensued. The walkout failed when the company refused to yield and offered bonuses to returning workers. ${ }^{18}$

The lost strike at Brunswick foreshadowed a series of setbacks for organized labor in the 1920s. The end of the First World War ushered in a decade that celebrated business values, extolled the virtues of rugged individualism, and castigated radicals and reds. Such an environment boded ill for the labor movement. The open shop campaign launched by some local business leaders merely compounded labor's plight. Some sought to neutralize unions; others wanted union-free workplaces. Statements claiming that powerful unions drove up wage rates and drove off new industries while undermining the American commitment to individualism and democracy became the hallmarks of the attack. ${ }^{19}$

These anti-union sentiments found expression in a range of employer tactics. Recently organized bakers, for example, found their request for wage increases met by an employer lockout. The Corn Belt Packing Company dismissed eight

17. Hendricks, "Dubuque's Economy," 7, 8; Iowa Writers' Program, Dubuque County History, 67; Len Kruse, "Riding the Milwaukee Road," Over 49 News \& Views, January 1992, 1-2; Dubuque Leader, 14 September 1956.

18. Len Kruse, "Memories of Brunswick," Over 49 News \& Views, December 1991, 1, 3, 4; Hendricks, "Dubuque's Economy," 7; Dubuque Telegraph Herald, 25, 27 March, 29 April, 13, 14, 15, 27 October 1919, 6 April 1920.

19. Dubuque Telegraph Herald, 24 April 1921; Dubuque Leader, 31 August 1956. 
union organizers and refused to deal with the representatives of the meat cutters local. Millworkers organized in 1919 but still made no progress with the city's mill owners. The building trades locals as a whole survived the decade in a weakened condition. Unionized machinists, tinners, molders, and teamsters went out on unsuccessful strikes during the twenties. In the aftermath of the walkouts, the machinists and tinners lost some members, but the teamsters and molders lost their respective unions. During a 1922 nationwide strike of railway shop workers to protest wage cuts, 950 employees of the Milwaukee shops also walked off the job. Although the number of strikers exceeded that of any other local work stoppage in the 1920s, the result was the same: a defeated union with fewer members. After beating back the trade unions in 1919, the Brunswick-Balke-Collender Company established a company union, giving its workers life insurance coverage, a cooperative buying plan, and recreation facilities, rather than negotiating workplace terms and conditions of employment. ${ }^{20}$ As the decade of the 1920 s ended, local unionists looked back at an era of reduced membership, lost strikes, and busted unions. During the next decade, organized labor experienced both the despair of economic collapse and the hope of reinvigorated unionism.

The Great Depression of the 1930s meant widespread unemployment and misery for the Dubuque working class. Among the city's manufacturing industries that employed nearly half of the laboring population, some layoffs began in the mid-1920s. Between 1927 and 1934, thirty firms employing 2,200 workers closed or left town, while the city gained thirteen new businesses that employed only three hundred. The Brunswick plant and the Milwaukee shops accounted for over half of these lost jobs. As part of a general restructuring, employment at the rail shops dropped from 1,600 in the early 1920 s to 600 when the shops were relocated in 1931, leaving only 25 employees by 1934 . Brunswick also cut back its peak employment of 1,650 to 900 in 1927. The business was sold

20. Dubuque Telegraph Herald, 6 July 1919, 3 August, 12 September, 6 October 1920, 24 April, 22 May 1921, 2 July, 21 September 1922; Dubuque Leader, 14 September 1956; Kruse, "Memories of Brunswick," 3, 4. 


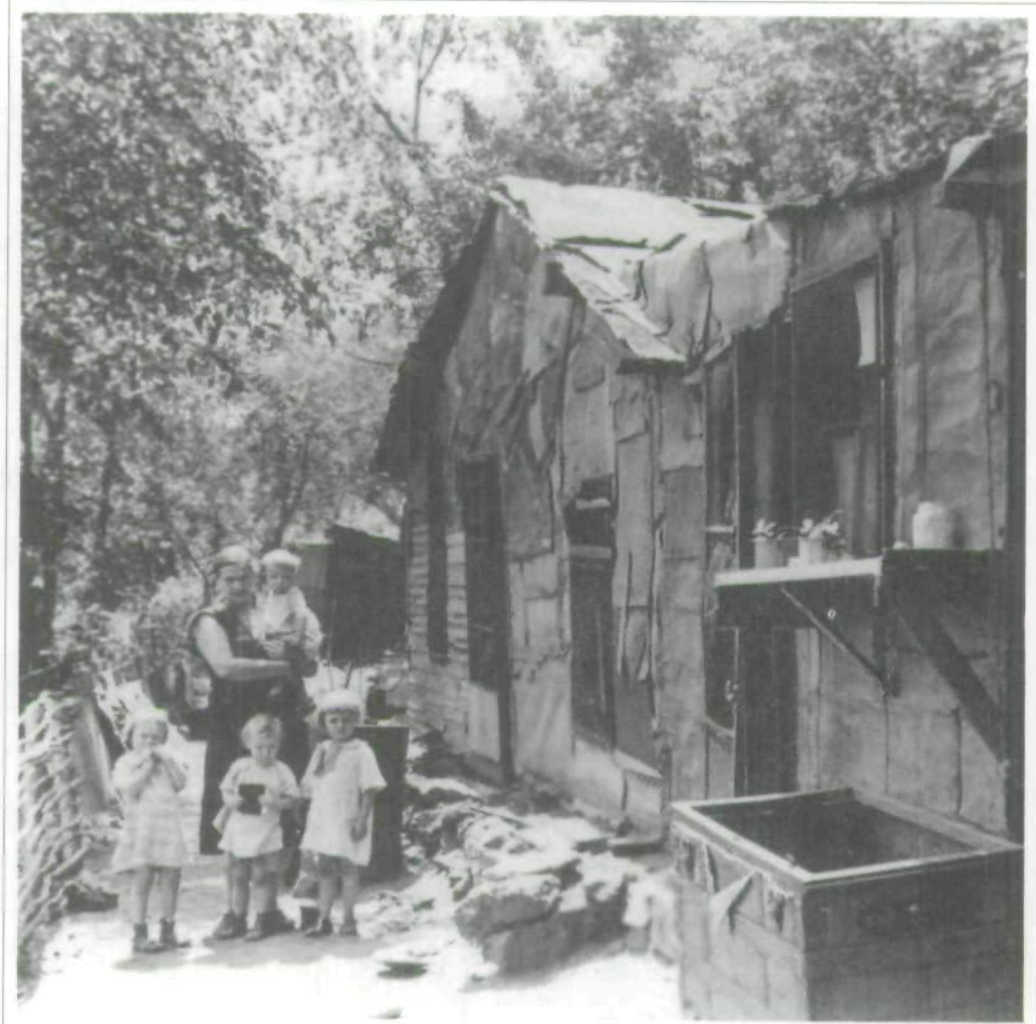

A family poses outside their "Hooverville" residence for an Iowa State Planning Board photographer about 1938. Courtesy Dubuque County Historical Society.

in April 1930 and closed permanently in December 1931. The demise of these two large operations contributed to a labor surplus that hampered union organizing efforts. The other important employers of labor, the sash and door mills, continued to operate with work forces reduced by two-thirds. Four local banks had also closed by the mid-1930s. ${ }^{21}$

Wages of Dubuque factory workers dropped by one-half between 1930 and 1935. One out of every five families

21. Hendricks, "Dubuque's Economy," 7-8; Jessie A. Bloodworth and Elizabeth J. Greenwood, The Personal Side (1939; reprint, New York, 1971), 4-5; Kruse, "Memories of Brunswick," 4; Kruse, "Riding the Milwaukee Road," 2. 
received some sort of relief. ${ }^{22}$ Joblessness fell hardest on workers in the building trades, on young people lacking training and experience, on female workers, on the few AfricanAmerican laborers, on those with disabilities, and on older wage earners. A cross section of Dubuque's unemployed workers offered their personal impressions of the economic distress they experienced to interviewers from the New Deal's Works Progress Administration between December 1937 and April 1938. The interviews revealed that jobless Dubuquers preferred work relief to direct relief, blamed mechanization and concentration of wealth for the depression, strongly endorsed Social Security, and argued that recovery required work that provides decent pay. Troubled by the economic devastation of unemployment and the resultant loss of homes and land, savings and securities, furniture and appliances, families drew support from one another, friends, and neighbors. Most of the families hoped that wise leadership would help the nation regain an economic vitality conducive to promoting a modestly comfortable standard of living for the working populace. ${ }^{23}$

To counter the economic hardships caused by the depression, President Franklin D. Roosevelt's administration inaugurated work relief projects. The most important of these New Deal agencies in Dubuque was the Works Progress Administration (WPA). The city's two major WPA construction projects, Eagle Point Park and the lock and dam, employed hundreds of jobless workers. In Dubuque County, as many as 1,200 people worked one, two, or three days per week on a variety of WPA projects. ${ }^{24}$

Ironically, the year 1933 was not only the worst year of the depression, but also the year that marked a turning point for organized labor. Workers organized locals that finally secured union recognition in three of the city's most impor-

22. Hendricks, "Dubuque's Economy," 8; Brimeyer and McCormick, Our Spirited Years, 77.

23. Bloodworth and Greenwood, The Personal Side.

24. Dubuque Telegraph Herald, 22 September, 10 November 1935, 19 January 1936, 1, 24, January, 17 May 1937, 11 February, 12, 22 September 1938; Brimeyer and McCormick, Our Spirited Years, 80-81. 


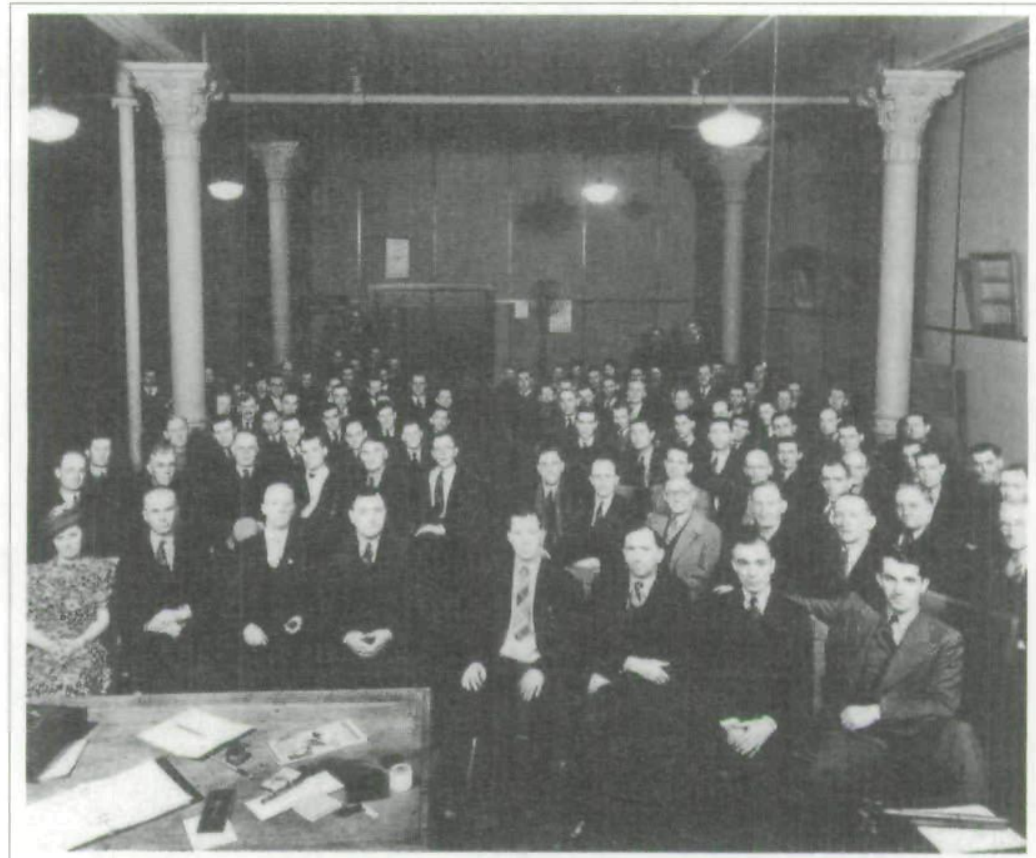

Members of the Machinist's Union meet in 1939, at the height of the period of union organizing in the wake of the National Labor Relations Act of 1935. Courtesy Bob Runde.

tant industries: meatpacking, metals fabricating, and wood products. Meat cutters at the recently opened Dubuque Packing Company, machinists at A. Y. McDonald Manufacturing Company, and woodworkers at Farley and Loetscher established the foundation for a revived labor movement. ${ }^{25}$

The late 1930s witnessed an impressive burst of union organizing, thanks to the passage of the National Labor Relations Act in 1935. For the first time, the federal government, by the provisions of this legislation, guaranteed to all privatesector employees the right to organize unions and engage in collective bargaining with employers free of restraint or coercion. Responding to this organizing stimulus, new locals appeared among iron workers, city and county employees, glaziers, patternmakers, fire fighters, postal clerks, laborers,

25. Dubuque Leader, 31 August, 7 September 1956. 
portable and stationary engineers, and communications workers. ${ }^{26}$

Not all of these gains were easily achieved. Wiped out in the 1920s, the teamsters and molders reorganized and survived conflicts with employers. The teamsters won a bitter strike against a local department store. The molders conducted a successful strike at A. Y. McDonald and Morrison Brothers and signed up additional members. The battery workers finally organized at General Dry Batteries, Inc. in December 1940, after the company fought them with stooges, a company union, and a "sweetheart" deal with a rival union. Tensions between union and management peaked among millworkers at Farley and Loetscher during confrontations in 1935 and 1939 marked by strikes and injunctions. The workers filed a large number of unfair practices charges against the company, and eventually received union recognition and pay increases. ${ }^{27}$

By the end of the 1930s, the local economy showed signs of improvement as business picked up and employment rose. Unions had waged some fierce struggles for union recognition and improved compensation and conditions. One of the great legacies of the New Deal era for organized labor was the actual legitimizing of unionization. Also, the passage of legislation creating Social Security, minimum wages and maximum hours, as well as the work relief programs, directly benefited working-class people. Flexing their newly developed political muscles, local unions played a critical role in electing city council candidates friendly to labor, beginning with the 1936 election. ${ }^{28}$ Ahead lay an era of unparalleled economic growth and union power.

FROM 1940 TO 1980, Dubuque's population increased 42 percent, from 43,892 to 62,321 . This rate of growth was slower than the national average but faster than the state of

26. Ibid.

27. Ibid.; Dubuque Telegraph Herald, 5, 7, 15, 16, 23 August 1935, 20 August, 19 November 1936, 10 March 1938, 10, 12, 18, 25 May 1939, 12 June 1977.

28. Dubuque Leader, 7, 14 September 1956. 
Iowa and some of its other cities. During this forty-year period the number of industrial workers doubled. These wage earners made up 36 percent of the total Dubuque County labor force in 1980. This rate of manufacturing employment put Dubuque far ahead of the national and state averages of 22 to 23 percent, and even surpassed the 29 percent figure for the industrial colossus of Detroit. ${ }^{29}$

While the industrial sector of Dubuque's economy grew in these years, the retail and service sectors also showed strength, bringing a corresponding increase in jobs. Downtown and westside malls and shopping districts provided the locales for the burgeoning retail trade. Health services steadily increased and constituted the largest single employment category in the service sector of the local economy. Two hospitals, Mercy Health Center and Finley Hospital, provided the major employment for health care workers. ${ }^{30}$

The era from 1940 to 1975 was a kind of golden age for Dubuque workers. The local economy surged ahead as inflation and unemployment remained low, jobs and productivity grew, and real wages and consumption increased. Through collective bargaining and strikes, local labor unions made advances not only in higher wages and shorter hours, but also in fringe benefits such as paid holidays, paid vacations, premium pay for night work, health insurance, and company pensions. Strong unions and well-paid jobs characterized the community. By 1979, Dubuquers enjoyed the second-highest median income in the state. In the same year, Dubuque ranked tenth nationally in per capita consumer goods spending. ${ }^{31}$ Most attributed these rankings not only to powerful unions, but also to two companies that dominated the local economy.

29. Petersen, "Dubuque," 446; City Focus (Quarterly Newsletter of the City of Dubuque) (October 1991), 3; ibid. (January 1992), 5; Bogue, Population of the United States, 72; Hendricks, "Dubuque's Economy," 4; Job Service of Iowa, Labor Force Summary: Annual Averages 1978-1989, 33, 37.

30. See Dubuque Area Industrial Development Corporation, A Business Profile of Dubuque, Iowa (Dubuque, 1977), and Dubuque Area Chamber of Commerce, 1980 Dubuque Area Industrial Directory (Dubuque, 1980).

31. Hendricks, "Dubuque's Economy," 9, 10, 12, 13; New York Times, 23 November 1981, 18A. 


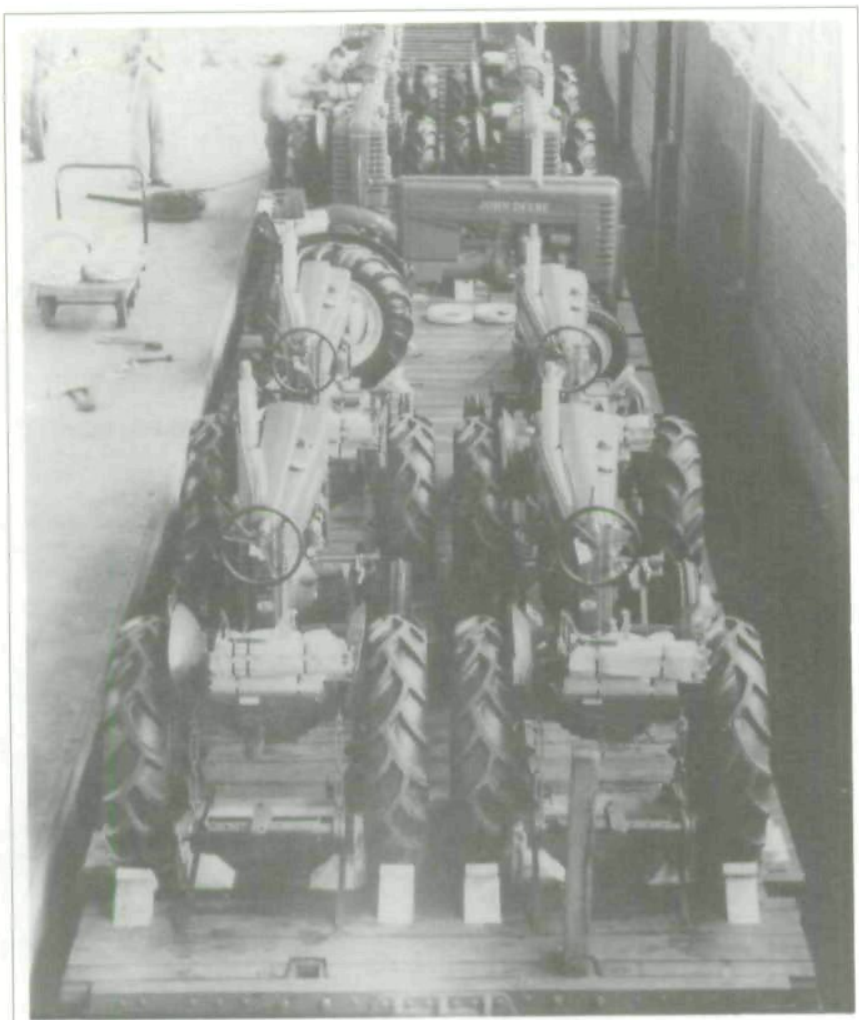

Tractors roll off the assembly line at the John Deere Dubuque Works plant about 1948. Courtesy John Deere Dubuque Works.

The Dubuque Packing Company and John Deere Dubuque Works became the area's two trademark high-pay industries. The Dubuque Packing Company opened in 1931 with 60 employees and reached a high of 3,500 in the early 1960s. The Amalgamated Meat Cutters and Butcher Workmen organized Dubuque Packing employees in 1933. Aside from a one-week strike in 1979, the union enjoyed amicable relations with the company. ${ }^{32}$ The John Deere Dubuque

32. Hendricks, "Dubuque's Economy," 10; [Amalgamated Meat Cutters and Butcher Workmen, Local 150], Souvenir Dedication Book 1966 (Dubuque, 1966); Mel Maas, president, United Food and Commercial Workers Union, Local 150A, interview with author, Dubuque, Iowa, 16 May 1991; 1980 Dubuque Area Industrial Directory, 35. 
Works plant opened just north of the city in 1946 with a work force of 800 . The factory produced farm tractors, but later turned to heavy construction and forestry equipment. After rival unions struggled to represent Deere employees, the United Auto Workers became the exclusive bargaining agent in August 1948. Periodic strikes, at the rate of about two per decade, including two wildcat strikes, marked management-labor relations at Deere. A 112-day walkout occurred in 1950. The UAW's strike victory that year meant gains in wages, benefits, and grievance procedures. By 1980, John Deere Dubuque Works had become an industrial behemoth. The company's 8,157 employees included 6,213 UAW members and accounted for almost half of the county's entire male-dominated manufacturing work force. ${ }^{33}$ Dubuque Packing Company, which had been the area's biggest employer until surpassed by John Deere in the 1960s, ranked second in 1980 with 2,700 employees. Between them, Deere and the Pack employed about two of every three of the city's manufacturing workers. ${ }^{34}$

In addition to these two giants, a third industry came to Dubuque in 1937 and became the fourth-largest employer. By 1980, Flexsteel Industries, a furniture manufacturer, employed 707, including about 500 union members. The Upholsterers Union was chartered on February 15, 1941, and won its first contract at Flexsteel by April 1.35 The area's thirdlargest employer, the Ertl Company, a toy manufacturer in the Dubuque County town of Dyersville, started as a family basement venture in 1945. In 1980 females accounted for 60 percent of the company's total work force that numbered

33. Hendricks, "Dubuque's Economy," 5, 9, 10; Floyd Bennett, The Spirit and Times of Local 94 UAW (Dubuque, 1978); 1980 Dubuque Area Industrial Directory, 35; Jim Waller, executive secretary, United Automobile Workers, Local 94, interview with author, Dubuque, Iowa, 28 May 1991.

34. 1980 Dubuque Area Industrial Directory, 35, 37.

35. George Mills, "Dubuque ... ," Des Moines Sunday Register Picture Magazine, 17 August 1952, 6; 1980 Dubuque Area Industrial Directory, 10, 35; Jim Feehan, president, United Steel Workers of America, Upholstery Division, Local 1861-U, interview with author, Dubuque, Iowa, 16 May 1991. 


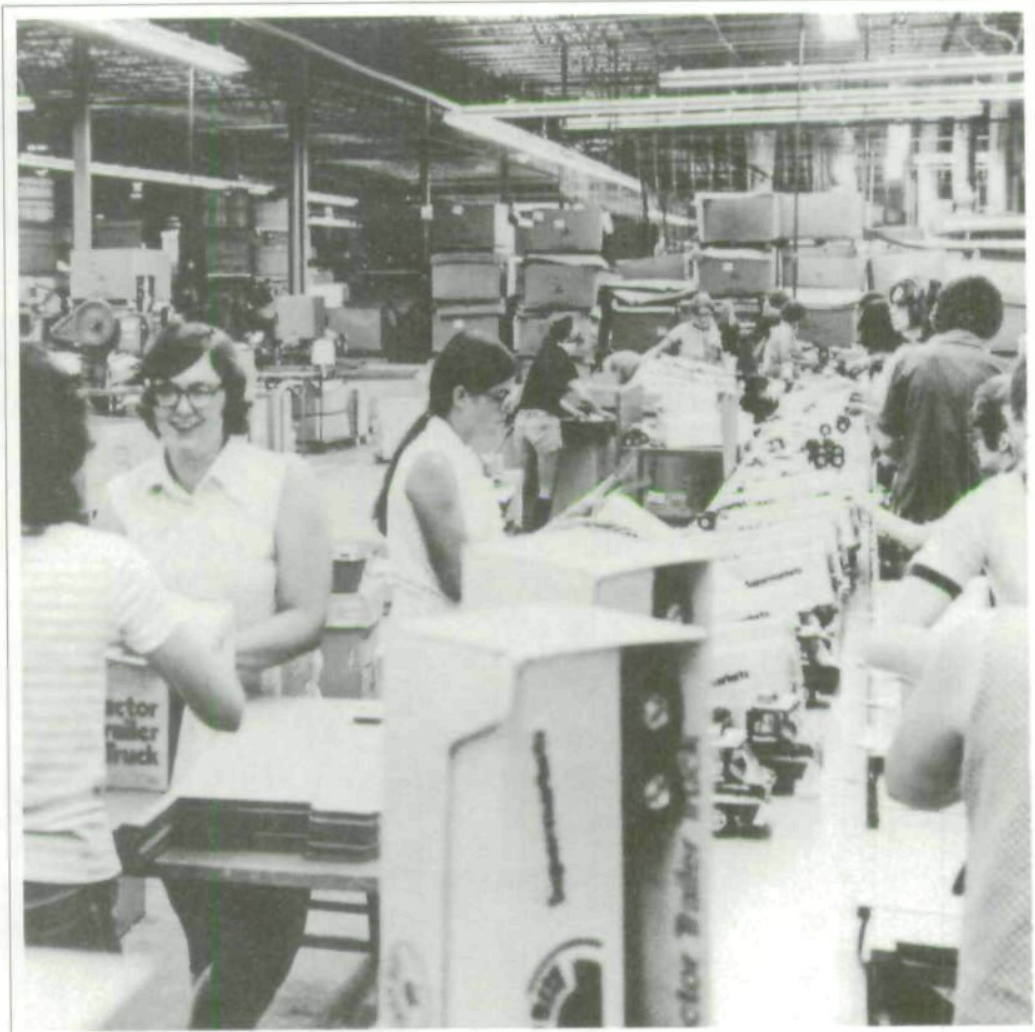

Women workers assemble toy trucks at Ertl Company in the late 1970s or early 1980s. Courtesy Ertl Company.

722. The UAW organized at Ertl in 1975 and negotiated its first contract a year later. ${ }^{36}$

Deere, the Pack, and Flexsteel ranked as the three highestpaying plants. By contrast, the traditionally meager wage millwork establishments closed in the 1960s and 1970s. In the early 1950 s the best-known company, Farley and Loetscher, still employed 1,250 people. A decade later, the factory closed. The company found itself squeezed by workers' demands for wage increases and low prices for millwork. In the 1970s Caradco (formerly Carr, Ryder and Adams)

36. 1980 Dubuque Area Industrial Directory, 35; Ron Brady, president, United Automobile Workers, Local 1982, telephone interview with author, 29 May 1991. 
phased out its operations and relocated, while Metz Manufacturing Company shut its doors for similar reasons. More than two thousand workers lost their jobs as a result of the mill closings. Dubuque's sash and door industry accounted for fewer than a hundred jobs by $1983 .{ }^{37}$ The virtual demise of high employment millwork caused only a temporary dislocation as the growing John Deere Company absorbed many of the jobless woodworkers.

The unionized work forces at the Pack, Deere, Ertl, and Flexsteel indicated that organized labor kept pace with the booming economic development. In the decade following the end of World War II, unionization also spread with the chartering of new locals among roofers, telephone workers, insurance agents, oil workers, movie operators, building service employees, glove workers, and gas workers. Unionization in the public sector intensified with the passage of the Iowa Public Employment Relations Act in 1974, which extended organization and bargaining rights to public employees. Public-sector unions existed among city and county government employees and school district workers, including teachers. By 1980, estimates of union membership in the Dubuque County labor force varied from 40 to 50 percent. ${ }^{38}$

For the forty years after 1940, Dubuque's economy, fueled by the expansion of manufacturing, reflected the boom conditions that prevailed across the nation after the Second World War. If unionized workers were paid well, they also consumed well, purchasing the goods and services that created a good business climate. But Dubuque's prosperity seemed inescapably linked to John Deere's prosperity. During the decade of the eighties, the town that labor and Deere built experienced economic misery.

37. Hendricks, "Dubuque's Economy," 9, 10, 12.

38. Dubuque Leader, 31 August, 14 September 1956, 5, 12 July, 16 August, 6 September, 11, 25 October 1974; Dubuque Telegraph Herald, 24, 25 April 1974. The rate of unionization reflects estimates from two areas: my calculations based on labor union figures presented in the 1980 Dubuque Area Industrial Directory, and conversations with several local trade union officials in May 1991. 
BETWEEN 1980 AND 1990, Dubuque's population dropped by about 4,800 , from 62,321 to 57,546 . The decline reflected a recession that rolled across the United States and hit manufacturing cities such as Dubuque with particular fury. Before 1980, recessions created few hardships for city residents. Even the large layoffs produced by the 1975 recession proved to be short-term, lasting only a year or less. Despite the national downturn in the production of durable goods, John Deere's Dubuque plant continued to hire more workers. Its addition of some 1,700 new jobs nearly wiped out the loss of 2,000 manufacturing jobs in the rest of Dubuque County's industries. ${ }^{39}$

But Deere's redemptive influence failed in the recession that began in 1979-80. This time, both the manufacturing and agricultural sectors declined, retail sales and home sales plummeted, and the city experienced unusually hard times. High interest rates and a related construction slump further complicated the economic crisis. The eighties' recession took its toll on the earnings of county residents. Between 1981 and 1988 , actual annual wages remained stagnant for production and related occupations and clerical/sales personnel, while service workers gained only 9 percent. Adjusting for inflation, employees suffered total income losses during the eightyear period of $\$ 5,448$ for production and related occupations, $\$ 4,018$ for clerical/sales jobs, and $\$ 2,385$ for service work. ${ }^{40}$

Between 1979 and 1982, 7,500 jobs disappeared in Dubuque County. Those years brought work force reductions in the thousands at Deere, hundreds at the Pack and Flexsteel, and tens and twenties at a variety of small manufacturers. The worst year of the recession was 1982. In Janu-

39. City Focus (October 1991), 3; ibid. (January 1992), 5; Hendricks, "Dubuque's Economy," 4, 5, 24.

40. U.S. Bureau of the Census, County Business Patterns, 1979-1989; Hendricks, "Dubuque's Economy," 4, 24, 25. Calculations of annual wages for these job classifications come from data found in Job Service of Iowa's The Dubuque County Wage Survey for 1981 and 1988, 3, 10-20. Figures for lost income because of inflation reflect national consumer prices information contained in the Council of Economic Advisors' Economic Indicators: January 1990 (Washington, DC, 1990), 24; See also Jerry Flint, "True Grit in the Heartland: A Visit to Dubuque, Iowa," Forbes, 28 March 1983, 130-37. 
ary of that year the Dubuque County unemployment rate hit 23 percent-inflated by a temporary shutdown of the Deere plant-while the year's average was 14.2 percent. These percentages exceeded state and national figures, and ranked as the worst since the Great Depression. By 1989, John Deere Dubuque Works was operating with a halved labor force $(4,200)$, and Dubuque Packing Company's dropped by onethird to 1,800. This amounted to a combined loss of roughly five thousand jobs at the two firms since $1980 .{ }^{41}$

With its strength in the manufacturing sector, organized labor sustained devastating membership losses. Union membership fell by as much as 40 percent, according to some estimates. ${ }^{42} \mathrm{~A}$ decade of deteriorating relations between manufacturing employers and their unions compounded the situation. Between 1976 and 1986, work stoppages involved tens of thousands of unionized employees. At FDL Foods (formerly the Dubuque Packing Company) packinghouse workers turned out in 1983 for five weeks and again in 1986 for seven weeks. In 1982 the upholsterers' walkout at Flexsteel lasted for eight-and-one-half weeks. The UAW strike at John Deere that lasted from August 1986 to February 1987 was the longest walkout. The sluggish economy and inflation increased tensions as companies sought to cut costs and reduce employment while workers sought to increase wages and maintain job security. Employers called workers' demands unreasonable, blamed unions for the loss of jobs, hired anti-labor consultants, and insisted on concessions. Organized laborers called employers greedy, filed unfair labor practice charges, grudgingly accepted some concessions, and accused employers of using union-busting tactics. ${ }^{43}$

41. Labor Force Summary, 1978-1989, 33, 37; Flint, "True Grit in the Heartland," 134; Hendricks, "Dubuque's Economy," 24; Dubuque Telegraph Herald, 18 March 1982; 1980 Dubuque Area Industrial Directory, 37; Dubuque Area Chamber of Commerce, 1988/89 Dubuque Area Industrial Directory (Dubuque, 1988), 55.

42. This estimate is based on my analysis of the 1980 and $1988 / 89$ industrial directories as well as on conversations with several trade union leaders in May 1991.

43. Labor Force Summary, 1978-1989, 33, 37; Mel Maas, interview, 16 May 1991; Jim Feehan, interview, 16 May 1991; Jim Waller, interview, 28 May 1991; Hendricks, "Dubuque's Economy," 26. 


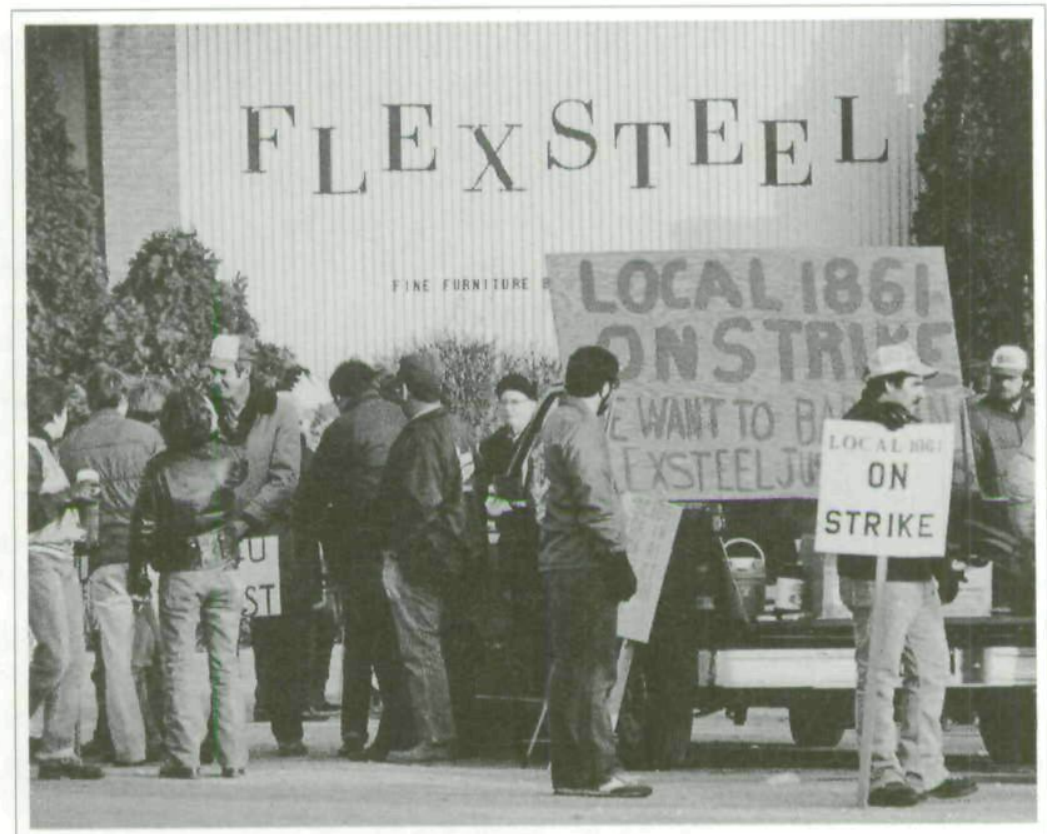

Strikers picket Flexteel Industries in the 1980s.

Courtesy Dubuque Telegraph Herald.

The sharp conflict between labor and management abated for two reasons. First, the rebound of the local economy beginning in 1986 and the increase of employment levels defused some of the animosity triggered by the sharp recession. Second, some management and union leaders realized that mutual antipathy was unproductive and costly. Seeking new ways to cooperate, they formed the Dubuque Area Labor-Management Council in 1988. The council continues to seek common ground for improving relations between employers and workers. ${ }^{44}$

By the time the Labor-Management Council began functioning, some new employment trends had emerged. From 1982 to 1989 , a shift from industrial jobs to service jobs was clearly under way. The 2,400 new jobs in Dubuque County

44. Labor Force Summary, 1978-1989, 33, 37; Chuck Isenhart, executive director, Dubuque Area Labor-Management Council, interview with author, Dubuque, Iowa, 26 October 1990; County Business Patterns, 1979-1989. 
came primarily in educational services, business services, and publishing. William C. Brown Publishers and CyCare Systems, Inc. represent two of these growth companies. Brown started publishing college textbooks and later diversified its offerings. CyCare provides software services to medical practices. They are medium-sized home-grown businesses that began as one-person operations. In 1988-89, Brown Publishing employed 506, having added 150 workers since 1982. During the same years, CyCare's 1,100 employees constituted a gain of 885 . Retail trade, on the other hand, showed little growth in the 1980s, except in the county's eating and drinking establishments, where employment jumped by 700 between 1983 and $1988 .{ }^{45}$

Changes in county employment by gender became important in the 1980s. While males continued to dominate manufacturing, except at the Ertl Company, a reversal occurred in ancillary services. There, men held two-thirds of the jobs in 1980 , but by $1988-89$, women accounted for twothirds of the work force. Although men constituted a clear majority in warehousing and distribution employment, women jobholders rose 45 percent from 1980 to $1988-89.46$ More and more Dubuque families relied on two paychecks rather than one.

During the 1980s Dubuque endured a recession that weakened many firms and destroyed a few, precipitated a decline in manufacturing employment, lowered workers' take-home pay, and reduced the ranks of organized labor. Some new employment patterns also appeared. Service-sector employment increased, as did the number of female nonmanufacturing employees. The decade of the eighties clearly altered Dubuque's economic landscape.

DURING THE PAST CENTURY AND A HALF, Dubuque experienced a constant economic evolution, the ebb and flow

45. County Business Patterns, 1979-1989; Labor Force Summary, 1978-1989, 33, 37; Dubuque Area Chamber of Commerce, 1982 Dubuque Area Industrial Directory (Dubuque, 1982), 43, 35; 1988/89 Dubuque Area Industrial Directory, 55, 58; Hendricks, "Dubuque's Economy," 30.

46. 1980 Dubuque Area Industrial Directory, 37, 38; 1988/89 Dubuque Area Industrial Directory, 1-48. 
of industrial enterprises. Lead mining, lumbering and millwork, railroading, meatpacking, and heavy equipment manufacturing dominated the local economy for successive periods of time. These dominant industries were always supplemented by a variety of small and medium-sized businesses. Over the years an expanding and hard-working labor force mined the lead, milled the logs, stoked the furnaces, forged the steel, bottled the beer, set the type, stitched the clothes, cut the meat, and fabricated the machinery. Beginning in the middle of the nineteenth century, the early craft unions, followed by advocates of the Knights of Labor and the American Federation of Labor, organized increasing numbers of local workers and established a solid base of unionization that remains unmatched in many parts of the country. The historical record indicates that these industrial workers and their unions helped etch the character of the Dubuque community.

The recovery following the 1980 s recession evoked some optimism from Dubuque wage earners about their city's economic future. By the late 1980s, the city had made progress in addressing two long-standing problems: land and transportation. The city's downtown business district and westside industrial park drew increased attention and attracted new, relocated, or expanded enterprises. A series of highway building projects promised economic development through better access. Those who advocated diversifying the local economy pointed to medical services, insurance, data processing, and tourism as areas of potential growth. But working-class people expressed concerns about such service and information sector jobs because they generally offered lower pay and fewer benefits than manufacturing employment. Local trade unions, with their strength traditionally derived from male workers having European ancestry and holding industrial jobs, face the challenge of organizing more nonmanufacturing employees in a work force increasingly characterized by gender, racial, and ethnic diversity. ${ }^{47}$

47. 1988/89 Dubuque Area Industrial Directory; Francis Giunta, president, Dubuque Federation of Labor, interview with author, Dubuque, Iowa, 13 May 1991; Larry M. Nagle et al., Overall Economic Development Program for the East Central Intergovernmental Region, 1990-1991 (Dubuque, 1990). 
These changing patterns of work and workers have influenced Dubuque's identity as a city where industrial production determines whether the community prospers or struggles. Manufacturing will continue to play a significant but more muted role in a local economy experiencing expansion of service/information employment. On the other hand, some workers note room for growth in industrial production, including nondurable manufacturing such as food processing. In 1989 the manufacturing sector still accounted for close to 30 percent of the Dubuque County work force. Union membership, coming in the largest numbers from Deere, the Pack, and teamsters' locals, still stands at an estimated one-third of the labor force. This compares with a national unionization rate of just under 17 percent. ${ }^{48}$ The Dubuque labor force, with a significant number of manufacturing workers and sturdy unionists, continues to play a vital role in the evolution of the city's economy, and in its identity as an industrial city.

48. Labor Force Summary, 1979-1989, 33, 37; 1988/89 Dubuque Area Industrial Directory; Nagle et al., Overall Economic Development Program, 19901991; Des Moines Register, 4 September 1989; Francis Giunta, interview, 13 May 1991. 
Copyright of Annals of Iowa is the property of State of Iowa, by \& through the State Historical Society of Iowa and its content may not be copied or emailed to multiple sites or posted to a listserv without the copyright holder's express written permission. However, users may print, download, or email articles for individual use. 